\title{
Profile of Thematic Learning Viewed from STEAM in the 2013 Curriculum for Grade IV Elementary School
}

\section{Kurniati Fadhilah ${ }^{1}$, Fenny Roshayanti ${ }^{2}$, Veryliana Purnamasari ${ }^{3}$}

\author{
1,2,3 Universitas PGRI Semarang, Semarang, Indonesia
}

\section{A R T I C L E I N F O}

Article history:

Received March 08, 2021

Revised March 11, 2021

Accepted April 30, 2021

Available online May 25, 2021

Kata Kunci:

Pembelajaran, Tematik,

STEAM, Kurikulum

Keywords:

Learning, Thematic, STEAM, Curriculum

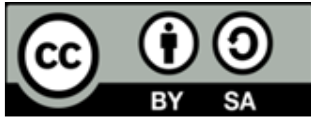

This is an open access article under the CC BY-SA license.

Copyright $(5) 2021$ by Author. Published by Universitas Pendidikan Ganesha.

A B S T R A C T

Education in Indonesia is still relatively low, because students have not been able to face the challenges of the industrial revolution 4.0. There needs to be an educational concept that is able to answer the challenges of the industrial revolution 4.0, one of which is STEAM (Science, Technology, Engineering, Art, Mathematics). This study aims to analyze the potential of STEAM contained in the Teacher's Book and Student's Book Theme 1-9 Revised 2017 grade IV Elementary School. This research is a qualitative descriptive study with the object of research directed to find out the potential of STEAM contained in the 2017 Revised Teacher's Book and Student's Book for Grade IV Elementary School. Data obtained from secondary data in the form of Teacher's Books and Revised 2017 Student Books for Class IV Elementary Schools that have been analyzed. The data collection method used the documentation analysis method so that the researchers analyzed the Theme Books 1-9 Class IV Elementary School. The data analysis method used is the Miles and Huberman model starting with data collection, data presentation, data reduction, and drawing conclusions and verification. The results show that there are facts that have STEAM potential and facts that have STEAM potential with an average of $80 \%$ of STEAM potential from the number of lessons in Themes 1-9. So, the results of the analysis of the 2017 Revised Teacher's Book and Theme Book for Grade IV Elementary School have the potential for STEAM. However, there are some learnings that do not have STEAM facts, so the learning does not have STEAM potential.

\section{INTRODUCTION}

The industrial revolution 4.0 requires humans to enter into technological developments. The industrial revolution 4.0 has fundamentally changed the way people think, live, and relate to others (W et al., 2020; Harahap, 2019). The Industrial Revolution 4.0 has an impact on all sides of life, including the world of education. The challenge of society and students in the industrial revolution 4.0 is that every 
human child has technology from birth even in the womb (Darise, 2019). As a result of that, the industrial revolution 4.0 has a major impact on the lives of the millennial generation and affects their social functioning in real life, many millennial generations struggle to maintain their existence on social media(W et al., 2020). The industrial revolution 4.0 demands that education be able to face the challenges of preparing and equipping students to have 21st century skills. Therefore, efforts must be made properly so that students can master and develop 21st century skills. 21st century skills: critical thinking skills , problem solving, communication, collaboration, and creativity (Alaloul et al., 2020; Siswanto, 2018). These 21st century skills must be possessed by every student, so that the quality of education can improve. Therefore, the role of the teacher is very important to realize the ability of students to face these challenges(Alismail \& McGuire, 2015; Budiyono, 2020; Sari \& Priatna, 2020).

Many efforts have been made by the government of the Ministry of National Education to establish various policies and efforts, among others by continuously seeking equal distribution/expanding access to education, improving the quality and relevance of education as well as developing school and community-based education management (Muttaqin \& Rais, 2018). This indicates that education in Indonesia has been expanded to all Indonesian people. However, equitable access to education and educational services is still far from the word "quality" (Fatkhuri, 2019). So, the quality of the expansion of education is still relatively low. This is in accordance with the results of the visa, based on PISA 2018 in the field of Reading, Indonesia's score is only 371, while in the field of Mathematics with a score of 379 with the same position as the field of Reading. In the field of Science, Indonesia's position is ninth from the bottom. Slightly increased compared to the other two fields with a score of 396 (Prastyo, 2020; Tohir, 2019). In this regard, Indonesia is still relatively low when compared to other countries. In Southeast Asia, Indonesia is still lagging behind with Singapore which still maintains its position as one of the best performers in mathematics, science, and literacy. Meanwhile, Vietnam has shown high performance in reading, mathematics, and scientific literacy and ranks 17th (Thien et al., 2015). As a result, in responding to the challenges of the Industrial Revolution 4.0, Indonesia is said to be still not good enough when compared to these countries. Indonesia is considered less good at responding to the challenges of the industrial revolution 4.0 compared to other countries. It can be seen that there are negative impacts caused by the industrial revolution 4.0 for Indonesia's young generation, ranging from radicalism, discrimination, the disappearance of local culture, brawls to criminal acts from social media and the real world resulting from a lack of understanding of multicultural education in the current era(Ningsih \& Rohman, 2018). The low quality of education in Indonesia is due to several existing problems. Problems that cannot be underestimated are not only costs but also other factors such as the lack of parental awareness of the importance of school for their children (Syahputri et al., 2019). Parents as the main pillars who support their children so that they can receive a proper education should provide full motivation and support to children so that children can be enthusiastic in undergoing education. This negative impact is still happening in the world of education.

The world of education is required to keep up with technological developments that are developing rapidly and be able to utilize information and communication technology as more and more sophisticated facilities to facilitate the learning process (Darise, 2019). The application of the use of technology as a facility for the learning process can be seen in developed countries such as Singapore, Canada, England, Australia, and Japan. These countries have transformed education covering several aspects, namely policies, teacher quality, and learning quality (Arifin, 2020). This shows that developed countries attach great importance to the quality of teachers so that people who are educated can become quality human beings so that in the future these young people can answer more complex challenges. Likewise, good quality teachers can provide interesting, innovative, creative, and interactive learning to students. Based on the statement above, it can be said that the way other countries respond to the challenges of the industrial revolution 4.0 is by improving the education system, that with education people are able to face a future that is always changing. Education is said to be able to answer the challenges of the industrial revolution 4.0, namely when it is being taught by a teacher in the classroom and outside the classroom. The teacher provides interesting learning that can motivate students so that they are not bored when participating in learning. One of them is by using Science, Technology, Engineering, Art, Mathematics (STEAM) learning.

STEAM is one of the educational breakthroughs in Indonesia that effectively responds to challenges not only today but also in the future (Anisimova et al., 2020). STEAM is an approach that integrates concepts and practices related to 21st century skills in the learning process, assessment and curriculum that integrates interdisciplinary knowledge(Gettings, 2016). STEAM is a combination of five different disciplines namely Science, Technology, Engineering, Art and Mathematics (Syahmani et al., 2021), integration of five scientific fields into a single learning system to solve specific problems drawn from real life(Zharylgassovaa et al., 2021). The STEAM approach can develop students' soft skills, namely 
working together, critical thinking, caring for the environment, responsibility, adaptability skills and creative thinking (Apriliana et al., 2018). STEAM can improve learning processes and outcomes, problem solving abilities, thinking skills critical of collaboration and integrity (Perignat \& Katz-Buonincontro, 2019). Also, the existence of STEAM can increase students' motivation in the learning process (Simamora et al., 2019), can increase cooperation, creativity and problem-solving skills that are not limited only in academic activities (Allina, 2018; How et al., 2019; Perignat \& Katz-Buonincontro, 2019). able to improve literacy skills(Şadoğlu, 2018) and can improve thinking skills such as imagination, creative innovation and other thinking skills(Costantino, 2018; Quigley et al., 2017). STEAM learning is in line with the 2013 Curriculum, because STEAM (Science, Technology, Engineering, Art, Mathematics) is the integration of science, technology, engineering, art, and mathematics into an integrated approach that can be implemented in learning in schools (Nurhikmayati, 2019) with the words Another example is STEAM in its interdisciplinary application ilmu (Costantino, 2018). The 2013 curriculum implements integrated learning, all subjects are combined in a theme compiled from sub-themes and learning.

The following are some previous studies that support researchers using STEAM (Science, Technology, Engineering, Art, Mathematics) in research. Research that shows that the positive implications for implementing the integration of STEM and Visual Arts in school rankings is low (Bahrum \& Ibrahim, 2018). Research showing that secondary school students acquire knowledge of STEAM content during GCC monitoring leads to more positive perceptions of science, technology, engineering, arts, and mathematics in the STEAM field (Jeong \& Kim, 2015). Research shows that students think that the integration of the STEAM approach in project-based learning is interesting, exciting and fun learning (Apriliana et al., 2018). This description is the reason this research was conducted. The focus of this research is to inform the profile of thematic learning in terms of STEAM (Science, Technology, Engineering, Art, Mathematics) in the 2013 Curriculum for grade IV Elementary School, precisely in the Teacher's Book and Student's Book. Through this study, information can be obtained about the potential of STEAM (Science, Technology, Engineering, Art, Mathematics) contained in thematic learning in elementary schools. Previously, there were studies that both discussed the STEAM approach. However, the difference between this study and the previous one is that previous research examined the development of mathematical handouts based on the STEAM approach. Meanwhile, this study analyzes the potential of STEAM (Science, Technology, Engineering, Art, Mathematics) contained in the Teacher's Book and Student Book Theme 1-9 Revision 2017 for grade IV Elementary School. With this new breakthrough, it is hoped that Indonesia can further improve the quality of its education and can make Indonesian students more develop science and technology. This new breakthrough is one of the answers to answer the challenges of the industrial revolution 4.0 which requires humans to have critical thinking skills in science, technology skills, have techniques, have an artistic spirit and be able to solve problems in this world based on mathematics.

\section{METHOD}

This research was conducted using qualitative descriptive research. The qualitative method according to Bogdan \& Taylor (in Moleong, 2012) is a research procedure that produces descriptive data in the form of words from the people and behaviors studied. The object of this research is the 2017 Revised Teacher's Book and Student's Book for Class IV Elementary School. The data obtained comes from secondary data in the form of documentation, namely the Teacher's Book and the Revised 2017 Student Book for Grade IV Elementary School, then the researcher analyzes the data contained in the book which later can be known how the potential of STEAM (Science, Technology, Engineering, Art, Mathematics) contained in the 2017 Revised Teacher's Book and Student's Book for Grade IV Elementary School. This is related to Novianto, A. \& Mustadi (2015) who analyzed the 2013 Curriculum integrated thematic textbooks compiled and published by the Ministry of Education and Culture in 2014 consisting of student books and teacher books. Methods of data collection using the method of documentation analysis. The data analysis method was carried out using the Milles dan Huberman model starting from data collection by collecting data in the Teacher's Book and Student Books Themes 1-9; presentation of data (data display) by presenting data in the form of tables, brief descriptions and charts; data reduction (data reduction) by summarizing all the data found in the form of tables, selecting the main things that are in accordance with the research, focusing on the things that are important, and discarding the unnecessary; drawing conclusions and verification (conclusion) by concluding all the data obtained and then verifying the results of the study with previous findings. 


\section{RESULT AND DISCUSSION}

\section{Result}

This research was conducted using descriptive qualitative research. The findings from the analysis of Teacher's Books and Student Books for Themes 1-9 Revised 2017 Grade IV Elementary Schools show that in each theme there are facts that have the potential for STEAM (Science, Technology, Engineering, Art, Mathematics). The results of the analysis show that the potential for STEAM already exists in each theme. However, there are sub-themes that do not have STEAM potential, namely Subtheme 4 in Themes 2, 4, 6, because those sub-themes are literacy habituation activities, so there is no STEAM potential. Sub-theme 4 in all themes consists of Project Activities and Literacy Habituation Activities. Literacy habituation activities are actually found in all themes. However, Project Activities do not exist in all themes, but only in Themes 1, 3, 5, 7, 8, and 9. So, in Theme 2, 4, 6 Sub-theme 4 there are no Project Activities. Based on the existing Project Activities, not all Project Activities in each Lesson in Subtheme 4 are potentially STEAM. In each lesson there are at most three STEAM potentials, namely in Theme 1 Sub-theme 1 Learning 2 and 3. In addition, in one lesson there are two, one, and some even do not have STEAM potential in it. The results of the analysis show that of the 9 theme books that have been analyzed, it shows that the number of potential STEAM is 173 out of 216 lessons. Based on the data that has been analyzed, the average potential for STEAM in each Theme is $80 \%$. The average result shows that the potential for STEAM from the facts in the 2017 Revised Teacher's Book and Student's Book for Class IV is considered quite a lot. However, the facts from the 2017 Revised Teacher's Book and Student's Book for Class IV Elementary Schools are still few that have STEAM potential. So, there needs to be an effort to increase the potential of STEAM so that it can be an inspiration for teachers. If the teacher is more creative and innovative, the existing facts can be made into STEAM potential.

\section{Discussion}

The results of the analysis of the 2017 Revised Teacher's Book and Student's Book of Class IV Elementary School that the researcher developed is an analysis of teaching and learning process activities that have the potential to develop and improve the abilities that exist in students. The potential for STEAM from the facts in the Teacher's Book and the Revised 2017 Class IV Student Book is already considered quite a lot. STEAM is also expected to be able to improve the quality of education in Indonesia through the 2013 Curriculum. Currently, the 2013 Curriculum uses thematic books consisting of Teacher's Books and Student's Books in their learning. The thematic book is used during teaching and learning activities to help achieve the objectives of the 2013 Curriculum. This thematic book describes teaching and learning process activities to help students achieve a learning goal of a basic competency. Teaching and learning process activities are expected to shape students into individuals who are able to think critically, creatively, innovatively, and able to work in teams. The way to form students to be able to do that is definitely with the intervention of the teacher. Teachers play an important role in carrying out the activities of the teaching and learning process. Teachers must be able to think about with what approach, what model, what kind of method, and how media that attracts the attention of students and is able to improve the quality and competence of students. Therefore, the researcher analyzed teacher books and student books that could potentially STEAM. Based on the analysis of the Teacher's Book and Student's Book, the teacher can find out that there are facts that have the potential to STEAM. Teachers can also develop and enrich students' learning experiences with the development of learning approaches that have been adapted to the facts of basic competencies that have STEAM potential. STEAM is one of the educational breakthroughs in Indonesia that effectively responds to challenges not only today but also in the future (Anisimova et al., 2020). STEAM is an approach that integrates concepts and practices related to 21st century skills in the learning process, assessment and curriculum that integrates interdisciplinary knowledge (Gettings, 2016).

STEAM is a combination of five different disciplines namely Science, Technology, Engineering, Art and Mathematics(Syahmani et al., 2021), integration of five scientific fields into a single learning system to solve specific problems drawn from real life(Zharylgassovaa et al., 2021). The STEAM approach can develop students' soft skills, namely working together, critical thinking, caring for the environment, responsibility, adaptability skills and creative thinking (Apriliana et al., 2018). STEAM can improve learning processes and outcomes, problem solving abilities, thinking skills critical of collaboration and integrity(Perignat \& Katz-Buonincontro, 2019). Also, the existence of STEAM can increase students' motivation in the learning process (Simamora et al., 2019), can increase cooperation, creativity and problem-solving skills that are not limited only in academic activities (Allina, 2018; How et al., 2019; Perignat \& Katz-Buonincontro, 2019). able to improve literacy skills (Şadoğlu, 2018) and can improve thinking skills such as imagination, creative innovation and other thinking skills (Costantino, 2018; Quigley et al., 2017). STEAM learning is in line with the 2013 Curriculum, because STEAM (Science, 
Technology, Engineering, Art, Mathematics) is the integration of science, technology, engineering, art, and mathematics into an integrated approach that can be implemented in learning in schools (Nurhikmayati, 2019) with the words Another example is STEAM in its interdisciplinary application ilmu (Costantino, 2018). The 2013 curriculum implements integrated learning, all subjects are combined in a theme compiled from sub-themes and learning.

The following is an example that can inspire teachers to implement STEAM, namely in Theme 2 "Always Save Energy" in Subtheme 1 "Energy Sources" Learning 3 there are facts in the form of KD Science regarding energy sources, changes in energy forms, and alternative energy sources (wind, water). , solar, geothermal, organic fuels, and nuclear) in everyday life. In the Student Book, the material is made into an activity to make windmills from paper and plastic. This has the potential to STEAM. However, teachers are expected to be able to develop their activities using the STEAM approach. The potential for STEAM that can be applied from these activities is to give the project tasks by taking into account the STEAM approach. First, the Science approach that the concept of a windmill which is an alternative energy source is useful for driving a rice or wheat pounder, moving a water pump, and so on. Second, the technology approach that the making of windmills can be seen through tutorials on the internet or videos on youtube. This youtube video is an information technology that can make it easier for students to understand the tasks given. Making windmills is assisted by tools, such as sticks/chopsticks, scissors, glue, and so on to assemble the windmills. Third, the Engineering approach is that by using a bending technique to make the propellers, then the propellers are assembled so that the shape can be good and it is ensured that the windmill can rotate when exposed to the wind. Fourth, the Art approach is found when students express their creativity such as drawing paper windmills or giving knick-knacks, giving colors to the windmills that are made. Fifth, the Mathematics approach is in measuring paper using a ruler when making paper propellers and cutting plastic to make the appropriate square. Square is a flat shape in mathematics. The length of the stick must be measured and adjusted not too long or short. The plastic propellers are cut to the same length and the right and left positions of the bottles are observed when perforating the bottle. Project assignments can develop the abilities and skills of students based on the STEAM approach. So, Theme 2 Sub-theme 3 Learning 3 is a fact that has STEAM potential.

Berikut ini terdapat contoh lagi pada Tema 7 "Indahnya Keragaman Negeriku" Subtema 2 "Indahnya Keragaman Budaya Negeriku" Pembelajaran 1 terdapat fakta berupa KD IPA mengenai macammacam gaya, antara lain: gaya otot, gaya listrik, gaya magnet, gaya gravitasi, dan gaya gesekan. Dalam buku siswa, materi tersebut dibuat menjadi suatu percobaan listrik menggunakan penggaris dan kertas. Namun, hal tersebut belum berpotensi STEAM. Sebab, pada percobaan listrik menggunakan penggaris dan kertas belum memenuhi aspek engineering pada STEAM. Kegiatan tersebut hanya percobaan/praktik, dilakukan dengan memotong kertas menjadi bagian-bagian kecil, gosok-gosok penggaris pada rambut, lalu dekatkan penggaris dengan potongan kertas kecil-kecil, sehingga kertas dapat tertarik dan menempel pada penggaris. Padahal, aspek engineering pada STEAM yaitu keterampilan yang dimiliki seseorang untuk mengoperasikan atau merangkai sesuatu (Munawar et al., 2019). Maka dari itu, guru diharapkan dapat mengembangkan setiap kegiatan pembelajaran dengan menggunakan pendekatan STEAM. Potensi STEAM yang dapat diterapkan dari materi tersebut yaitu dengan memberikan tugas proyek membuat tong sampah berjalan. Tong sampah berjalan dibuat dengan menerapkan pendekatan STEAM. Pertama, pendekatan Science bahwa konsep gaya yang digunakan saat membuat tong sampah berjalan yaitu gaya listrik. Gaya adalah dorongan atau tarikan yang dapat menyebabkan benda bergerak atau berubah bentuk. Gaya mempunyai banyak jenis sesuai dengan sumber yang melakukan gaya. Macam-macam gaya antara lain: gaya otot, gaya listrik, gaya magnet, gaya gravitasi, dan gaya gesek. Kedua, pendekatan Technology bahwa ketika akan membuat tong sampah berjalan dapat dilihat di internet atau video di youtube.

The following is another example in Theme 7 "The Beauty of the Diversity of My Country" Subtheme 2 "The Beauty of the Diversity of My Country's Culture" Lesson 1 contains facts in the form of KD IPA regarding various forces, including: muscle force, electric force, magnetic force, gravitational force, and friction force. In the student book, the material is made into an electrical experiment using a ruler and paper. However, it is not yet STEAM potential. Because, in electrical experiments using a ruler and paper, it has not met the engineering aspects of STEAM. This activity is just an experiment/practice, it is done by cutting the paper into small parts, rubbing the ruler on the hair, then bringing the ruler closer to the small pieces of paper, so that the paper can be attracted and stick to the ruler. In fact, the engineering aspect of STEAM is the skill that a person has to operate or assemble something (Munawar et al., 2019). Therefore, teachers are expected to be able to develop each learning activity using the STEAM approach. The potential for STEAM that can be applied from these materials is by giving the project task of making a walking trash can. The walking trash can is made by applying the STEAM approach. First, the Science approach that the concept of force used when making a walking trash can is an electric force. A force is a push or a pull that can cause an object to move or change shape. Style has many types according to the 
source that performs the style. Types of force include: muscle force, electric force, magnetic force, gravitational force, and frictional force. Second, Technology's approach that when it comes to making the trash can run it can be seen on the internet or videos on YouTube. This youtube video is an information technology that can make it easier for students to understand the tasks given. The materials and tools needed are a trash can with a lid, two wheels, two small bottle caps, a small power cord, a small switch, a large battery, screws. Third, the Engineering approach that its manufacture begins with collecting all materials and tools. Prepare a trash can, make a hole in the bottom right, bottom left and middle back. Make eyes from two unused lids, stick them in the top front trash can. Electrical circuit that can run the wheels. Stick the cable into the trash can. Then stick the wired switch in the back hole. Stick the battery in the trash can. Connect the cables with batteries. Install the wheels on the right and left of the trash can, securing it with screws. Close the trash can. Turn on the trash can by pressing the on button on the switch. The trash can is running. Fourth, Art's approach is that the art element in making trash cans is when you put your eyes in the trash can. The color of the trash can is sought that is bright to make it attractive, the eyes are taken from the bottle caps with different colors. Fifth, the Mathematical approach that the manufacture of trash cans requires mathematical concepts when measuring the cables used to make electricity flow in the trash cans. Project assignments can develop the abilities and skills of students based on the STEAM approach. So, Theme 7 Sub-theme 2 Learning 1 is a STEAM-potential fact.

The results of the analysis of the 2017 Revised Teacher's Book and Student's Book for Class IV Elementary School that the researcher developed is an analysis of teaching and learning activities that have the potential for STEAM to develop and improve the abilities that exist in students. This can be used for teaching and learning activities by implementing STEAM in elementary schools. This is in accordance with what Ramadani (2020) stated that mathematical handouts based on the STEAM approach on flatsided geometry can be used as a supporting learning resource to study flat-sided geometry in an interdisciplinary way that integrates five fields of science, namely science, technology, engineering. , art, and mathematics so that it can increase students' interest in learning mathematics, improve students' understanding of the material for flat-sided shapes, increase students' creativity, and build students' character. In the 2017 Revised Teacher's Book and Student's Book for Grade IV Elementary School, there are facts that have STEAM potential and facts that have STEAM potential. So, the thematic learning profile in terms of STEAM in the 2013 fourth grade Elementary School Curriculum shows that the Teacher Books and 2017 Revised Theme Books for Grade IV Elementary Schools analyzed have potential. However, there are some learnings that do not have STEAM facts, so that learning does not have STEAM potential. It is hoped that teachers can develop lessons that have STEAM potential so that the teaching and learning process activities can be more creative, innovative, imaginative, and fun. This was also conveyed by Munawar et al. (2019) which says that teachers or accompanying caregivers should be co-discoverers with children.

\section{CONCLUSION}

The 2017 Revised Teacher's Book and Student's Book for Grade IV Elementary School has been analyzed and developed so that it can be used in STEAM teaching and learning activities to develop and improve the abilities that exist in students. It is hoped that the results of this research will be able to answer the challenges of the industrial revolution 4.0 so that students can be more creative, innovative, and independent. from now on using the STEAM approach in teaching and learning activities, so that teaching and learning activities can be more creative, innovative, imaginative, and fun.

\section{REFERENCES}

Alaloul, W. S., Liew, M. S., Zawawi, N. A. W. A., \& Kennedy, I. B. (2020). Industrial Revolution 4.0 in the construction industry: Challenges and opportunities for stakeholders. Ain Shams Engineering Journal, 11(1), 225-230. https://doi.org/10.1016/j.asej.2019.08.010.

Alismail, H. A., \& McGuire, P. (2015). 21 St Century Standards and Curriculum: Current Research and Practice. Journal of Education and Practice, 6(6), 150-155. https://files.eric.ed.gov/fulltext/EJ1083656.pdf.

Allina, B. (2018). The development of STEAM educational policy to promote student creativity and social empowerment. Arts Education Policy Review, 119(2), 77-87. https://doi.org/10.1080/10632913.2017.1296392.

Anisimova, T. I., Sabirova, F. M., \& Shatunova, O. V. (2020). Formation of design and research competencies in future teachers in the framework of STEAM education. International Journal of Emerging 
Technologies in Learning, 15(2), 204-217. https: //doi.org/10.3991/ijet.v15i02.11537.

Apriliana, M. R., Ridwan, A., Hadinugrahaningsih, T., \& Rahmawati, Y. (2018). Pengembangan Soft Skills Peserta Didik melalui Integrasi Pendekatan Science, Technology, Engineering, Arts, and Mathematics (STEAM) dalam Pembelajaran Asam Basa. JRPK: Jurnal Riset Pendidikan Kimia, 8(2), 42-51. https://doi.org/10.21009/jrpk.082.05.

Arifin, Z. (2020). Transformasi Pendidikan di Negara Maju: Inisiatif Filosofis Pengembangan Mutu Pendidikan di Indonesia. Journal of Islamic Studies, 16 (1), 38-56. https: //doi.org/10.47466/hikmah.v16i1.166.

Bahrum, S., \& Ibrahim, M. N. (2018). Kebolehgunaan Modul “steAm ” dalam Pengajaran dan Pembelajaran Pendidikan Seni Visual Sekolah Rendah Usability of " steAm " Module in Teaching and Learning of Visual Arts Education in Primary School. Jurnal Seni Dan Pendidikan Seni, 6, 65-79. https://ejournal.upsi.edu.my/index.php/JSPS/article/download/2282/1603/.

Budiyono. (2020). Inovasi Pemanfaatan Teknologi Sebagai Media Pembelajaran di Era Revolusi 4.0 Budiyono. Jurnal Kependidikan, 6(2), 300-309. https://doi.org/10.33394/jk.v6i2.2475.

Costantino, T. (2018). STEAM by another name: Transdisciplinary practice in art and design education. Arts Education Policy Review, 100-106. https: //doi.org/10.1080/10632913.2017.1292973.

Darise, G. N. (2019). Implementasi Kurikulum 2013 Revisi Sebagai Solusi Alternatif Pendidikan Di Indonesia Dalam Menghadapi Revolusi Industri. Ilmu Iqra', 13(2), 41-53. http://journal.iainmanado.ac.id/index.php/JII/article/view/967.

Fatkhuri, F. (2019). Desentralisasi Pendidikan di Indonesia: Korupsi dan Problem Politik Kekuasaan. KEMUDI : Jurnal Ilmu Pemerintahan, 3(2), 278-297. https://doi.org/10.31629/kemudi.v3i2.874.

Gettings, M. (2016). Putting It All Together: STEAM, PBL, Scientific Method, and the Studio Habits of Mind. Art Education, 69(4), 10-11. https://doi.org/10.1080/00043125.2016.1176472.

Harahap, N. J. (2019). Mahasiswa Dan Revolusi Industri 4.0. Ecobisma (Jurnal Ekonomi, Bisnis Dan Manajemen), 6(1), 70-78. https://doi.org/10.36987/ecobi.v6i1.38.

How, M., Loong, W., \& Hung, D. (2019). Educing AI-Thinking in Science, Technology, Engineering, Arts, and Mathematics (STEAM) Education. Education Sciences, 9(3), 1-41. https://doi.org/https://www.mdpi.com/2227-7102/9/3/184\#.

Jeong, S., \& Kim, H. (2015). The effect of a climate change monitoring program on students' knowledge and perceptions of STEAM education in Korea. Eurasia Journal of Mathematics, Science and Technology Education, 11(6), 1321-1338. https: //doi.org/10.12973/eurasia.2015.1390a.

Moleong, L. (2012). Metodologi Penelitian Kualitatif. PT Remaja Rosdakarya.

Munawar, M., Roshayanti, F., \& Sugiyanti, S. (2019). Implementation of Steam (Science Technology Engineering Art Mathematics) - Based Early Childhood Education Learning In Semarang City. Ceria (Cerdas Energik Responsif Inovatif Adaptif), 2(5), 276. https: //doi.org/10.22460/ceria.v2i5.p276-285.

Muttaqin, Z., \& Rais, M. (2018). Menelusuri Pendidikan Kecakapan Hidup (Life Skill) Pada Mata Pelajaran Ppkn Siswa Kelas Iv Di Sdn 1 Terong Tawah Kec.Labuapi Kabupaten Lombok Barat Tahun Pelajaran 2014/2015. CIVICUS: Pendidikan-Penelitian-Pengabdian Pendidikan Pancasila Dan Kewarganegaraan, 4(2), 87. https: //doi.org/10.31764/civicus.v4i2.345.

Ningsih, Y. E., \& Rohman, A. (2018). Pendidikan Multikultural: Penguatan Identitas Nasional Di Era Revolusi Industri 4.0. UNWAHA Jombang, 1(September), 44-50.

Novianto, A. \& Mustadi, A. (2015). Analisis Buku Teks Muatan Tematik Integratif, Scientific Approach, Dan Authentic Assessment Sekolah Dasar. Analisis Buku Teks Muatan Tematik Integratif, Scientific Approach, Dan Authentic Assessment Sekolah Dasar, 45(1), 1-15. https: //doi.org/10.21831/jk.v45i1.7181.

Nurhikmayati, I. (2019). Implementasi STEAM Dalam Pembelajaran Matematika. Didactical Mathematics, 1(2), 41-50. https://doi.org/10.31949/dmj.v1i2.1508.

Perignat, E., \& Katz-Buonincontro, J. (2019). STEAM in practice and research: An integrative literature review. Thinking Skills and Creativity, 31,31-43. https://doi.org/10.1016/j.tsc.2018.10.002.

Prastyo, H. (2020). Pengembangan Soal Matematika Model PISA Menggunakan Konteks Kalimantan Timur. Jurnal Padegogik, 3(1), 1-44. https://doi.org/10.35974/jpd.v3i1.2230.

Quigley, C. F., Herro, D., \& Jamil, F. M. (2017). Developing a Conceptual Model of STEAM Teaching Practices. School Science and Mathematics, 117(1-2), 1-12. https: //doi.org/10.1111/ssm.12201.

Ramadani, E. (2020). Pengembangan Handout Matematika Berbasis Pendekatan STEAM (Science, Technology, Engineering, Arts, and Mathematics) Pada Materi Bangun Ruang Sisi Datar Untuk Siswa Kelas VIII SMP. Universitas Jambi.

Şadoğlu, G. P. (2018). Engineering students' opinions on science literacy. Universal Journal of Educational 
Research, 6(8), 1819-1830. https://doi.org/10.13189/ujer.2018.060827.

Sari, R. M. M., \& Priatna, N. (2020). Model-Model Pembelajaran di Era Revolusi Industri 4.0 (E-Learning, MLearning, AR-Learning dan VR-Learning). Jurnal Ilmiah Fakultas Keguruan Dan Ilmu Pendidikan, 6(1), 107-115. http://ejournal.unsub.ac.id/index.php/FKIP/article/view/699/591.

Simamora, R. E., Saragih, S., \& Hasratuddin, H. (2019). Improving Students' Mathematical Problem Solving Ability and Self-Efficacy through Guided Discovery Learning in Local Culture Context. International Electronic Journal of Mathematics Education, 14(1), 61-72. https://doi.org/10.12973/iejme/3966.

Siswanto, J. (2018). Keefektifan Pembelajaran Fisika dengan Pendekatan STEM untuk Meningkatkan Kreativitas Mahasiswa. Jurnal Penelitian Pembelajaran Fisika, 9(2), 133-137. https://doi.org/10.26877/jp2f.v9i2.3183.

Syahmani, S., Hafizah, E., Sauqina, S., Adnan, M. Bin, \& Ibrahim, M. H. (2021). STEAM Approach to Improve Environmental Education Innovation and Literacy in Waste Management: Bibliometric Research. Indonesian Journal on Learning and Advanced Education (IJOLAE), 3(2), 130-141. https: //doi.org/10.23917/ijolae.v3i2.12782.

Syahputri, N. R., Yanzi, H., \& Halim, A. (2019). Peran Program Bosda Dalam Perluasan Akses Pendidikan Di SMKN 1 Bandar Lampung. Jurnal Kultur Demokrasi, vol v, 1-15. http://jurnal.fkip.unila.ac.id/index.php/JKD/article/view/18355.

Thien, L. M., Darmawan, I. G. N., \& Ong, M. Y. (2015). Affective characteristics and mathematics performance in Indonesia, Malaysia, and Thailand: what can PISA 2012 data tell us? Large-Scale Assessments in Education, 3(1). https://doi.org/10.1186/s40536-015-0013-z.

Tohir, M. (2019). Hasil PISA Indonesia Tahun 2018 Turun Dibanding Tahun 2015. 2018-2019. https://doi.org/10.31219/osf.io/pcjvx.

W, R. W. A., Poluakan, M. V., Dikayuana, D., Wibowo, H., \& Raharjo, S. T. (2020). Potret Generasi Milenial Pada Era Revolusi Industri 4.0. Focus: Jurnal Pekerjaan Sosial, 2(2), 187. https: //doi.org/10.24198/focus.v2i2.26241.

Zharylgassovaa, P., Assilbayeva, F., Saidakhmetova, L., \& Arenova, A. (2021). Psychological and pedagogical foundations of practice-oriented learning of future STEAM teachers. Thinking Skills and Creativity, 41. https://doi.org/10.1016/j.tsc.2021.100886. 